\title{
Level of Satisfaction on Sports Facilities and Infrastructure among Students of Sport-Specific Class in A Senior High School
}

\author{
Asmaa Abusamra ${ }^{1}$, Slamet Lestari ${ }^{2}$, Dyssa Arfiesta Valentin Fajri ${ }^{2}$ \\ ${ }^{1}$ The University College of Applied Science, Gaza, Palestine \\ ${ }^{2}$ Universitas Negeri Yogyakarta, Yogyakarta, DIY, Indonesia \\ Corresponding author: Slamet Lestari (e-mail: slamet_lestari@uny.ac.id)
}

\begin{abstract}
This study aims to investigate the students' levels of satisfaction on sportspecific class facilities and infrastructure in SMA N 4 Yogyakarta. This is a quantitative descriptive study that involves as many as 64 students of the tenth and eleventh grades of sport-specific classes. The data of this study were collected through surveys and observations before being analyzed using the descriptive statistics method. The results of this study show that the student level of satisfaction on sports facilities and infrastructure in SMA N 4 Yogyakarta is in the "moderate" category. Furthermore, seen from the categories of the service quality determinants, the aspect of reliability is in the "high" category while the tangibility is in the "very low" category.
\end{abstract}

Keywords: satisfaction level, facilities and infrastructure, sport-specific class, senior high school

\section{Tingkat Kepuasan Siswa Kelas Khusus Olahraga terhadap Fasilitas dan Infrastruktur Olahraga di Sekolah Menengah Atas (SMA)}

\begin{abstract}
Abstrak: Penelitian ini bertujuan untuk menyelidiki tingkat kepuasan siswa terhadap fasilitas dan infrastruktur kelas khusus olahraga di SMA N 4 Yogyakarta. Penelitian ini adalah penelitian deskriptif kuantitatif yang melibatkan sebanyak 64 siswa dari kelas sepuluh dan sebelas kelas khusus olahraga. Data penelitian ini dikumpulkan melalui survei dan observasi sebelum dianalisis menggunakan metode statistik deskriptif. Hasil penelitian ini menunjukkan bahwa tingkat kepuasan siswa terhadap fasilitas dan infrastruktur olahraga di SMA N 4 Yogyakarta berada dalam kategori "sedang". Selain itu, dilihat dari kategori penentu kualitas layanan, aspek keandalan berada dalam kategori "tinggi" sedangkan tangibilitas berada dalam kategori "sangat rendah".
\end{abstract}

Kata kunci: tingkat kepuasan, fasilitas dan infrastruktur, kelas khusus olahraga, sekolah menengah atas

\section{INTRODUCTION}

Education is one of the fundamental factors of national development. No country can achieve sustainable economic development without substantial investments in human resources (Ozturk, 2011). According to law no. 20/2003 on the National Education System, education means conscious and well-planned efforts to create learning environments and learning processes so that a learner can develop his/her full potential 
for acquiring spirituality, religiosity, self-control, personality, intelligence, morals, and noble characters, and skills that one needs for him/herself, for the community, for the nation, and the State.

To achieve success, educational institutions are supported by a variety of strategies to improve education services. The services are provided to meet students' expectation which affects their academic and non-academic achievements. To improve student achievement, an education institution requires specific services, such as facilities and infrastructure, guidance and counseling, interest and talent development, etc. (Fintor, 2013) suggests that several factors are affecting the student or school performance. The aspects affecting student performance are gender, place of residence, family background, learning attitude, motivation, and connection. Then, the factors influencing the school performance are infrastructure, location, school size, atmosphere, as well as the number and composition of students. Moreover, teacher performance depends on some aspects, including teacher professional training, teaching attitude, motivation, and collaboration. Educational infrastructures are the physical assets and facilities that contribute directly or remotely to the teaching and learning process in the educational system (Musa \& Baharum, 2012).

In law no. 20/2013 article 45 on National Education System, it is amended that every formal and non-formal education unit shall provide educational facilities and required equipment in accordance with pedagogical criteria for learners' development and growth for physical, intellectual, social, emotional, and spiritual abilities. In the Special Region of Yogyakarta, several schools are selected by the local government to be the pioneer schools for conducting sport-specific classes. The specific classes are expected to be the place where young athletes study as well as develop their talents in sports.

Law no. 3/2005 Part IV Article 11 paragraph (2) concerning the National Sports System amends that the central and regional government are responsible for providing services and facilities as well as assuring the implementation of sports activities for every citizen without discrimination. Besides, according to law number 3/2005 Part II Article 25 paragraph (6) on the National Sports System, to foster sports achievements, education institutions may establish sports units, sports classes, sports and training centers, and sports schools as well as hold regular sports events. According to the Decree of the Yogyakarta Mayor Number 57/KEP/2010, SMA N 4 Yogyakarta is appointed to become 
one of the pioneers of sports schools to integrated improve the sports performance and guide the young athletes in formal education. Therefore, the SMA N 4 Principal's Decree No 800/23 on the establishment of Sports Class Management Team for the 2012/2013 academic year is the follow up of the decree mentioned above.

Sumaryanto (2010) states that the reason behind the establishment of sportspecific classes in the school lies in the sports facilities. The sports facilities in SMA N 4 Yogyakarta are somehow more complete compared to other schools, so the education office decides to add sport-specific classes at the high school. The sport-specific class at SMA N 4 Yogyakarta is a special class for students who have sports achievements, talents, and abilities. In other words, this class is intended for young athletes to be trained at schools. The students of this class are provided with training programs coached by trainers who are specially invited to train and foster their achievement at school. The sport-specific classes at SMA N 4 Yogyakarta conduct sports training every Wednesday and Saturday, starting from 06:00 a.m. to 08:30 a.m. The list of sports in SMA N 4 Yogyakarta is presented in table 1.

Table 1. The List of Sports in Sport-Specific Classes in SMA N 4 Yogyakarta in the 2018/2019 Academic Year

\begin{tabular}{cccc}
\hline No. & Sport & No. & Sport \\
\hline 1. & Basketball & 6. & Volleyball \\
2. & Football & 7. & Taekwondo \\
3. & Archery & 8. & Swimming \\
4. & Athletics & 9. & Table Tennis \\
5. & Karate & 10. & Badminton \\
\hline
\end{tabular}

The sport-specific classes coaching services are inseparable from the facilities and infrastructure in the school. As previously mentioned, the school has more advantages in terms of sports facilities and infrastructure compared to other schools in Yogyakarta. However, not all facilities and infrastructure to support student achievement in sportspecific class programs are owned by the school. The school only has the right of usage for those facilities and infrastructure. Below is the list of facilities and infrastructure for the sport-specific classes. 
Table 2. The List of Sports Infrastructure with the Right of Usage

\begin{tabular}{llc}
\hline No. & Infrastructure & Total \\
\hline 1. & Football Field & 1 \\
2. & Basketball Court & 2 \\
3. & Athletic Arena & 1 \\
\hline
\end{tabular}

Table 3. The List of Sports Equipment Owned by the School

\begin{tabular}{llc}
\hline No. & Equipment & Total \\
\hline 1. & Pingpong Ball & 120 \\
2. & Pingpong Net & 4 \\
3. & Synthetic Shuttlecock & 15 \\
4. & Badminton Rackets & 10 \\
5. & Electronic Whistle & 5 \\
6. & Volleyball (ball) & 20 \\
7. & Volleyball Net & 2 \\
8. & Soccer-ball & 20 \\
9. & Basketball (ball) & 20 \\
10. & Gymnastic Mattress & 5 \\
\hline
\end{tabular}

Table 4. The List of Infrastructure Owned by the School

\begin{tabular}{clc}
\hline No. & Infrastructure & Total \\
\hline 1. & Tennis ball court & 1 \\
2. & Hall & 1 \\
\hline
\end{tabular}

Tables 2, 3, and 4 show that there are some facilities, infrastructure, and equipment needed but not owned by the school. This condition is surely affecting student satisfaction as (Wilkins \& Balakrishnan, 2013) identify that the quality of teachers, the quality of the building, and the use of effective technology are the main determinants of student satisfaction.

\section{METHOD}

This is a quantitative descriptive study aiming to examine the level of student satisfaction of sports facilities and infrastructure in SMA N 4 Yogyakarta. This study employed (Parasuraman, Zeithaml, \& Berry, 1988) service quality determinants consisting of some aspects, namely reliability, responsiveness, trustworthiness, empathy, and tangibility. This research was carried out in SMA N 4 Yogyakarta, from May 5 to September 26, 2019. The participants of this study were students of sport-specific classes (X and XII Social Classes) at SMA N 4 Yogyakarta in the 2018/2019 academic year. The data of this 
study were collected using close-ended questionnaires. After being obtained, the data were analyzed using the descriptive statistic technique.

\section{RESULTS}

The data were collected using close-ended questionnaires consisting of 46 multiple choice questions with four answers for each question. The questionnaires were distributed to 64 students. The summary of the survey results is presented below.

Table 5. Student Level of Satisfaction of the Sports Facilities and Infrastructure in SMA N 4 Yogyakarta

\begin{tabular}{lll}
\hline No. & Category & $\mathbf{\%}$ \\
\hline 1. & Very High & 0.0 \\
2. & High & 25.0 \\
3. & Moderate & 48.4 \\
4. & Low & 25.0 \\
5. & Very Low & 1.6 \\
\hline
\end{tabular}

Theable 5 and figure 1 show that most of the students think that the facilities and infrastructure in the school are in the moderate category (48.4\%). The level of student satisfaction viewed from several aspects is presented in table 6 .

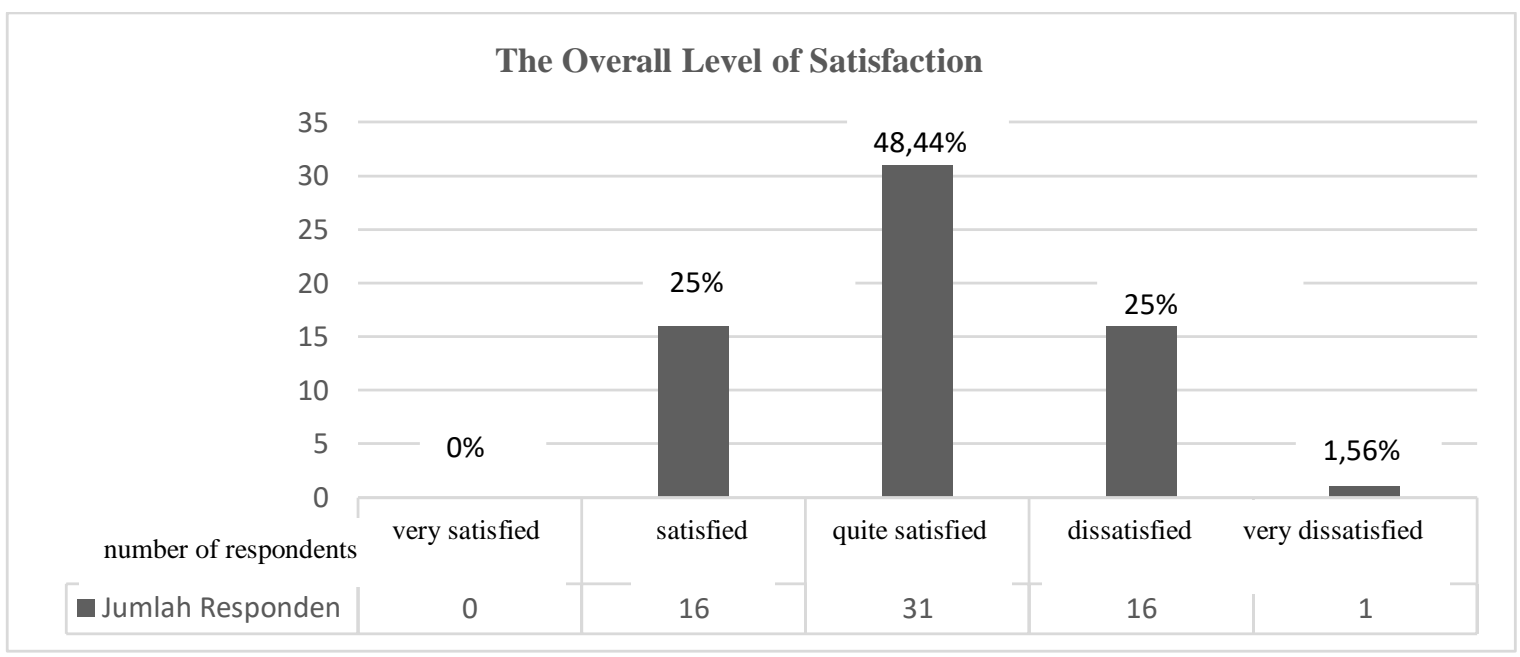

Figure 1. The Histogram of the Student Level of Satisfaction of the Infrastructure and Facilities

Table 6. The Level of Students Satisfaction of Infrastructure and Facilities (each aspect)

\begin{tabular}{ccccccc}
\hline \multirow{2}{*}{ No. } & \multirow{2}{*}{ Category } & \multicolumn{5}{c}{ Satisfaction Determinant } \\
\cline { 3 - 6 } & & Tangibility & Empathy & Trustworthiness & Responsibility & Reliability \\
\hline 1. & Very High & $9.3 \%$ & $6.2 \%$ & $1.5 \%$ & $3.1 \%$ & $0.0 \%$ \\
2. & High & $21.8 \%$ & $28.1 \%$ & $39.0 \%$ & $28.1 \%$ & $42.2 \%$
\end{tabular}




\begin{tabular}{clccccc}
\hline \multirow{2}{*}{ No. } & \multirow{2}{*}{ Category } & \multicolumn{5}{c}{ Satisfaction Determinant } \\
\cline { 3 - 6 } & & Tangibility & Empathy & Trustworthiness & Responsibility & Reliability \\
\hline 3. & Moderate & $40.6 \%$ & $34.3 \%$ & $32.8 \%$ & $39.0 \%$ & $28.1 \%$ \\
4. & Low & $21.8 \%$ & $26.5 \%$ & $20.3 \%$ & $23.4 \%$ & $20.3 \%$ \\
5. & Very Low & $62.5 \%$ & $4.6 \%$ & $6.2 \%$ & $6.25 \%$ & $9.4 \%$ \\
\hline
\end{tabular}

The questionnaire used to collect the data is constructed based on satisfaction determinants (see table 7), namely tangibility (8 items), empathy (9 items), trustworthiness (9 items), reliability (10 items), and responsiveness (10 items). From those determinants, it is known that the reliability aspect is chosen by most students (42.2\%) for being in the "high" category. Moreover, the tangibility factor is chosen by most of the students $(62.5 \%)$ for being in the "very low" category.

Tabel 7. The Statistics of Student Level of Satisfaction of Sport-specific Classes Facilities and Infrastructure

\begin{tabular}{lccccc}
\hline \multirow{2}{*}{ Statistic } & \multicolumn{5}{c}{ Satisfaction Determinant } \\
\cline { 2 - 6 } & Tangibility & Empathy & Trustworthiness & Responsiveness & Reliability \\
\hline Mean & 20.4 & 24.4 & 26.6 & 23.7 & 23.6 \\
Total Item & 8 & 9 & 9 & 10 & 10 \\
Ideal Minimum Score & 8 & 9 & 9 & 10 & 10 \\
Ideal Maximum Score & 32 & 36 & 36 & 40 & 40 \\
Minimum Obtained Score & 11 & 13 & 10 & 10 & 13 \\
Maximum Obtained Score & 29 & 33 & 36 & 34 & 30 \\
\hline
\end{tabular}

\section{DISCUSSION}

This study aims to investigate the level of student satisfaction of the sports infrastructure and facilities at SMA N 4 Yogyakarta. Five satisfaction determinants adopted in this study are reliability, responsiveness, trustworthiness, empathy, and tangibility (Parasuraman et al., 1988). From the results of this study, it is found that student satisfaction is in the "moderate" level (48.4\%). It can also be seen that one of the determinants of service quality, reliability, belongs to the "high" category as it is chosen by most of the students (42.2\%). Meanwhile, the aspect of tangibility is considered to be in the "very low" category by the majority of students $(62.5 \%)$ because the services provided are considered not satisfying by the students as the users.

When viewed from the score attainment for each item, item number 28 , which belongs to the responsiveness aspect, gets the lowest score (141). The school is not quite 
responsive in handling repairs. Then, the second-lowest attainment (146) is item number 14, which belongs to the empathy aspect. This item gets a low score due to the difficulties of using the infrastructure and. Then, from the tangibility aspect, the lowest item attainment is in item number 2 . This item is related to the availability of facilities and infrastructure. The infrastructure in the school somehow does not fulfill the students' needs, for example, the dry football field. Thus, some students should join others doing other sports exercise. The students doing archery should join those doing football, and those doing athletic should join students doing basketball. Some sports even have no regular practice schedule because of the limited facilities. The schools manage the infrastructure for swimming, volleyball, and badminton classes by renting a court and pool paid by the government funds. The football class is also conducted in a rented field which is not quite good in terms of quality. These school shortcomings should be eliminated by providing standard facilities and infrastructure.

Facilities and infrastructure are important factors in training students in sportspecific classes. This is in line with (Wicker, Hallmann, \& Breuer, 2013) stating that all types of sports infrastructure have a positive impact on sports participation in general. Thus, the availability of adequate facilities and infrastructure will make the training run well. Moreover, the student will be encouraged to perform better both individually and in groups. The quality of facilities and infrastructure is shown from student satisfaction. (Weerasinghe \& Fernando, 2017) define satisfaction level as a short-term attitude that is resulted from evaluating student experience, services, and educational facilities. Students will feel satisfied if their hopes and needs are met. Then, when they are satisfied with the facilities and infrastructure, they will achieve more in competitions. (Hill \& Epps, 2010) argued that along with physical facilities, equipment and materials surrounding them have a great impact on students' satisfaction. Therefore, El-Hilali, Al-Jaber, \& Hussein (2015) suggest that educational institutions spend much money on improving facilities and upgrading classrooms' and labs' equipment. The more comfortable the sports facilities and infrastructure are, the more satisfied the students become.

Educational services can be provided well if they meet the students' expectations and needs. If the services are in accordance with what the students expect, they will be satisfied. In contrast, when they think that the service does not meet their needs, they will not be satisfied. Things that can initiate student dissatisfaction are the discrepancy 
between students' expectations and the reality experienced, educational personnel's unpleasant behavior, as well as the school atmosphere, buildings, and environment. (Alves, Mainardes, \& Raposo, 2010) argue that positive student perception has significant effects on their satisfaction.

\section{CONCLUSION}

The results indicated that (1) the level of student satisfaction of sport-specific classes is in the "moderate" category; and (2) based on the satisfaction determinants, the reliability aspect is chosen by the majority of students (42.2\%) for being in the "high" category, and the tangibility factor is chosen by most of the students (62.5\%) for being in the "very low" category. Based on this result, the school needs to improve the quality of services, especially in the aspect of tangibility which covers the sports facility and infrastructure eligibility, quantity, cleanliness, and completeness.

\section{Acknowledgement}

This research received no specific grant from any funding agency in the public, commercial, or not-for profit sectors.

\section{REFERENCES}

Alves, H., Mainardes, E. W., \& Raposo, M. (2010). A relationship approach to higher education institution stakeholder management. Tertiary Education and Management. https://doi.org/10.1080/13583883.2010.497314

El-Hilali, N., Al-Jaber, S., \& Hussein, L. (2015). Students' satisfaction and achievement and absorption capacity in higher education. Procedia - Social and Behavioral Sciences. https://doi.org/10.1016/j.sbspro.2015.02.384

Fintor, J. G. (2013). Factors determining student achievement. Hungarian Educational Researcch Journal. https://doi.org/10.14413/herj2013.03.06

Hill, M. C., \& Epps, K. K. (2010). The impact of physical classroom environment on student satisfaction and student evaluation of teaching in the university environment. Academy of Educational Leadership Journal.

Keputusan Walikota Yogyakarta Nomor 57/KEP/2010 tentang Penunjukan SMA N 4 Kota Yogyakarta sebagai Rintisan Sekolah Olahraga.

Menteri Riset dan Pendidikan Tinggi. (2015). Peraturan Pemerintah RI Nomor 19, Tahun 2005, tentang Standar Nasional Pendidikan.

Musa, M. F., \& Baharum, Z. A. (2012). Higher education physical assets and facilities. Procedia - Social and Behavioral Sciences. https://doi.org/10.1016/j.sbspro.2012.08.051

Ozturk, I. (2011). The role of education in economic development: a theoretical perspective. SSRN Electronic Journal. https://doi.org/10.2139/ssrn.1137541 
Parasuraman, A., Zeithaml, V. A., \& Berry, L. L. (1988). Serqual: a multiple-item scale for measuring consumer perceptions of service quality. Journal of Retailing. https://doi.org/10.1016/S0148-2963(99)00084-3

Republik Indonesia. (2003). Undang-undang RI Nomor 20, Tahun 2003, tentang Sistem Pendidikan Nasional. Jakarta: Republik Indonesia

Republik Indonesia. (2005). Undang-undang RI Nomor 3, Tahun 2005, tentang Sistem Keolahragaan Nasional. Jakarta: Republik Indonesia

Sumaryanto. (Juli 2010). Pengelolaan Pendidikan Kelas Khusus Olahraga Menuju Tercapainya Prestasi Olahraga. Makalah. Disajikan dalam Seminar Kelas Khusus Olahraga, di SMA N 4 Yogyakarta.

Surat Keputusan Kepala SMA N 4 Yogyakarta Nomor 800/023 Tahun 2012 tentang Pembentukan Tim Pengelola Kelas Khusus Olahraga Tahun Pelajaran 2012/2013.

Weerasinghe, S., \& Fernando, R. L. . (2017). Students' satisfaction in higher education literature review. American Journal of Educational Research. https://doi.org/10.12691/education-5-5-9

Wicker, P., Hallmann, K., \& Breuer, C. (2013). Analyzing the impact of sport infrastructure on sport participation using geo-coded data: evidence from multilevel models. Sport Management Review. https://doi.org/10.1016/j.smr.2012.05.001

Wilkins, S., \& Balakrishnan, M. S. (2013). Assessing student satisfaction in transnational higher education. International Journal of Educational Management. https://doi.org/10.1108/09513541311297568 